Journal of Engineering and Applied Sciences 14 (Special Issue 7): 9995-10009, 2019

ISSN: 1816-949X

(C) Medwell Journals, 2019

\title{
Physicochemical Properties and Water Quality Index of Groundwater of Selected Wells in Najaf City Southern Iraq
}

\author{
${ }^{1}$ Rahman Fayyadh, ${ }^{2}$ Zainab Ismail and ${ }^{3}$ Hussain Musa Hussain and ${ }^{1}$ Lotfi Aleya \\ ${ }^{1}$ Chrono-Environnement Laboratoire, UMR CNRS 6249, \\ Bourgogne Franche-Comte University F-25030 Besancon, France \\ ${ }^{2}$ Department of Physics, Faculty of Science, Al-Muthanna University, Iraq \\ ${ }^{3}$ Department of Geology, Faculty of Science, University of Kufa, Iraq
}

\begin{abstract}
The area which located along the road area between the cities of Najaf and Karbala areas are very important from hydrogeological used towards the groundwater reservoir which called Dibdibba formation. The reveal part of this sandy formation allows for replenishing and keeping its water by the rainwater penetration and surface flood. Groundwater movement flows through the reservoir from the West to the East and Southeast direction, so, it is unconfined aquifer which means the top surface (water table) is open for permeable materials. This area between the two cities invested for decades due to its importance in addition to the hydrogeological feature of the water reservoirs and hydraulic specifications. Many groundwater wells were drilled in this area to use this water resource for many purposes of farming in particular. There are many water wells in this infiltrated water reservoir upper region represented by the composition Dibdibba formation have been exploited as a sandstone fan or fan-shaped (alluvial fans) according to its sedimentary environment. This water-based reservoir in part on natural nutrition where the rains start this reservoir depletion of stocks over exploited of water in addition to the low levels of nutrition and natural reservoir groundwater and the exposure portion of the formation Dibdibba Sandy helped to renew and sustain its groundwater during the penetration of rainwater and surface water. This water-based reservoir in part on natural nutrition rain then this stock began gradually decreasing and downward due to over exploitation of water in addition to low natural nutrition levels of the groundwater reservoir. Groundwater quality in this reservoir characterized to be higher concentrated with dissolved salts. The results of Water quality index (Wqi) values display that the groundwater of present study location predicted to be severely contaminated and non-suitable for drinking usage at all sites of the wells.
\end{abstract}

Key words: Water quality index, hydrogeology, groundwater, physicochemical properties, contaminated, particular

\section{INTRODUCTION}

Dibdibba formation name which appears in all wells of this aquifer was first utilized by Macfadyen to beds revealed near the city of Basrah in Southern Iraq and Northern Kuwait where about 150 m of locally cross-bedded sands, gravels and carbonate or argillaceous cement sand, clays, sandstones, conglomerates and siltstones are exposed (Fig. 1). Owen and Nasr described the formation from wells of the Zubair field, it comprises gravel and sand containing pebbles of igneous rocks and white quartz, often cemented into a hard grit (Owen and Nasr, 1958). Beds of limestone, marl and silt were reported from wells in Nahr Umr field, Kifl field and at Mussaiyiab field (Elliot et al., 1954; Kasim, 1960 and Kasim, 1962).

The formation ungraded and often cross-bedded sequence of gravels and sands accompanied by subordinate intercalated beds or lenses of sandy clay, conglomerate carbonate or evaporite, cemented siltstone and sandstone (Alsharhan and Nairn, 1997).

In the region of Dibdibba formation southern Iraq the water supply is chiefly dependent on the rainfall, fortunately, high porosity of the sandstone and sands, plenty of the water may seep into the ground and be stored or may drain into local surface depressions in which some water gradually transpire into the ground and some evaporates and underground drainage is toward the Euphrates and Shatt al Arab rivers, down both dip and topographic slope (Al-Naqib, 1963). Wqi concept primarily used by Horton (1965), the quality of water from the side of their chemical, physical and biological parameters and ensure its quality is important before it is used for several purposes like potable water, agricultural industrial and recreational, etc. (Sargaonkar and Deshpande, 2003). The common Wqi was advanced

Corresponding Author: Lotfi Aleya, Chrono-Environnement Laboratoire, UMR CNRS 6249,

Bourgogne Franche-Comte University, F-25030 Besancon, France Tel: +33(0)381665764,

Fax: +33(0)381665797 


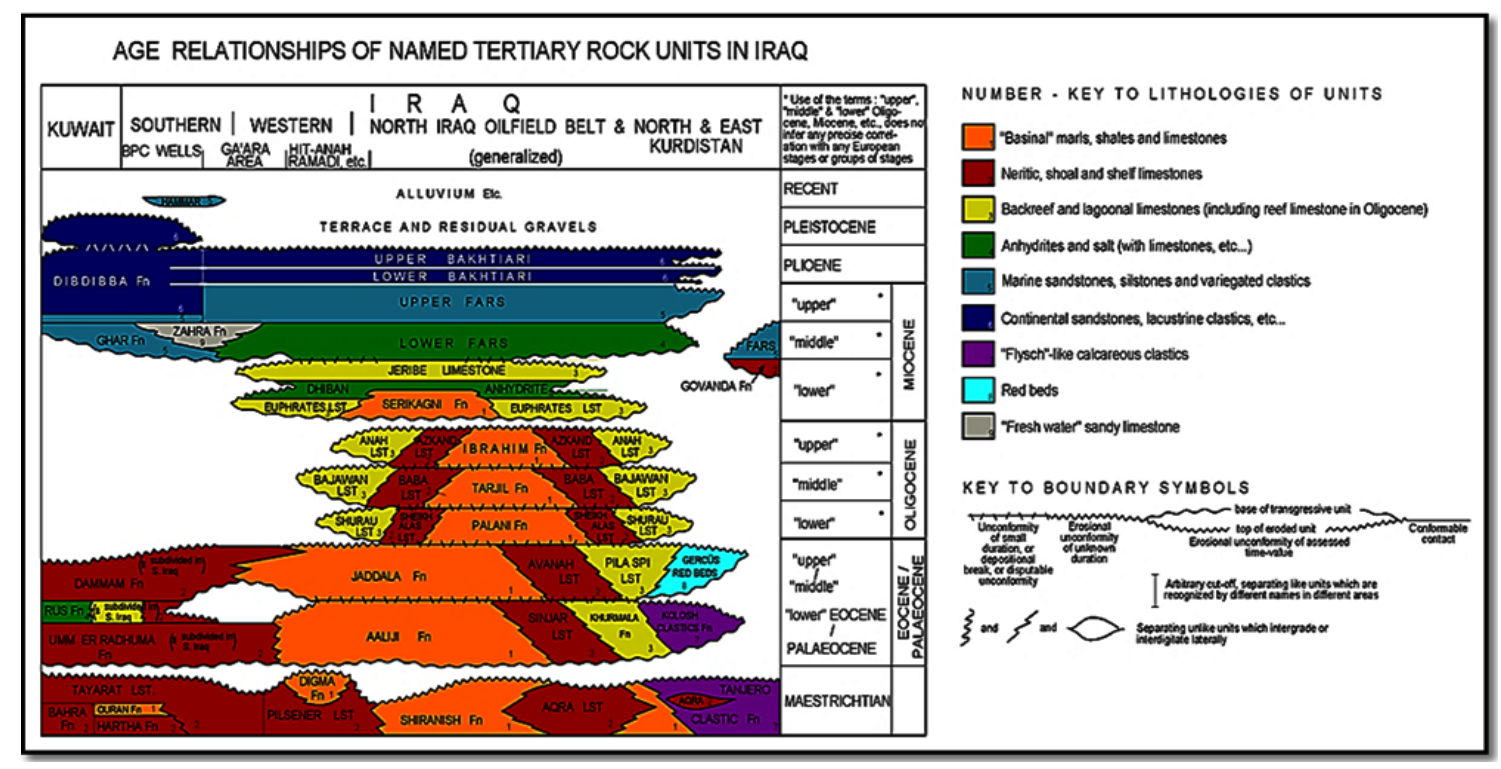

Fig. 1: Age relationships of named tertiary rocks units in Iraq

by Brown et al. (1970). Although, the Wqi founded on very serious parameters can show a simple indication of water quality (Yogedra and Puttaiah, 2008). Wqi is a classification shows the composite effect of diversified water quality parameters calculated count on the groundwater suitability for human consumption (Ramakrishnaiah et al., 2009).

In this study, the index includes the following eleven parameters: $\mathrm{pH}$ : potential Hydrogen ion concentration; EC: Electrical Conductivity; TDS: Total Dissolved Solids, calcium, magnesium, potassium, sodium, chloride, sulfate, bicarbonate and nitrate. In Iraq, many groundwater bodies recharge through vertical downward percolation of precipitation from the surface also indirect vertical seepage, about $100-300 \mathrm{~mm}$ of precipitation per year on the Mesopotamian flood plain and Jezira area and over half of Iraq situated within the semi-arid and arid zones (with $<150 \mathrm{~mm} /$ year rainfall) (Alsam et al., 1990).

The goal of this study is to investigate the groundwater quality of Dibdibba aquifer in Najaf city in the South of Iraq to know if it suitable for human consumption by using then the concept of Water quality index (Wqi).

\section{MATERIALS AND METHODS}

Study area: This area is situated between longitudes $\left(44^{\circ} .1840-44^{\circ} .3320\right)$ East and latitudes $\left(32^{\circ} .3088\right.$ 32.1180 ) North in Najaf city South of Iraq about $120 \mathrm{~km}$ Southwest of Baghdad (Fig. 2). Variations of recent recharge during dry and wet years have reportedly ranged between 2.2 and $12 \mathrm{~mm}$ per year. for the Dibdibba formation in Iraq. From the tectonic side study area located in the Mesopotamian zone within stable shelf and contains the two rivers Tigris and Euphrates within central and South of Iraq also covered with the sediments of quaternary (Fig. 3) (Buday and Jassim, 1987; Al Kadhimi et al., 1996; Jassim and Goff, 2006).

The hydrological position of the study area is placed within the Mesopotamian plain aquifer system (Fig. 4) (Jassim and Goff, 2006).This formation is a continental environment originally, fed by rain and floods surface and so, it is natural that the groundwater of it is a continental environment either the quality in a range of calcium, sulfate and sodium chlorides. Total dissolved solids are generally high, it ranges between $2593-4777 \mathrm{mgL}^{-1}$ which not fit for human drinking purposes according to the standards adopted by the food and agriculture organization and Iraqi standards for drinking water (Anonymous, 2001). The soil nature in the area and depth of groundwater qualified this water to agricultural uses because it contains a high percentage of the sand which maintains only $20 \%$ of irrigation water to maintain what plants need from elements as though the groundwater depth is major than $5 \mathrm{~m}$ which helps to not collect water and salts within zone of plants root (Mohammad, 2012).

The Eastern borders of the reservoir end by the disappearing of the geological formation and its water reservoir then turn into a semi-confined reservoir then confined near the Euphrates river and a ration of the water is discharged into the quaternary sediments above it (Al-Jawad et al., 2001). An official survey found that 


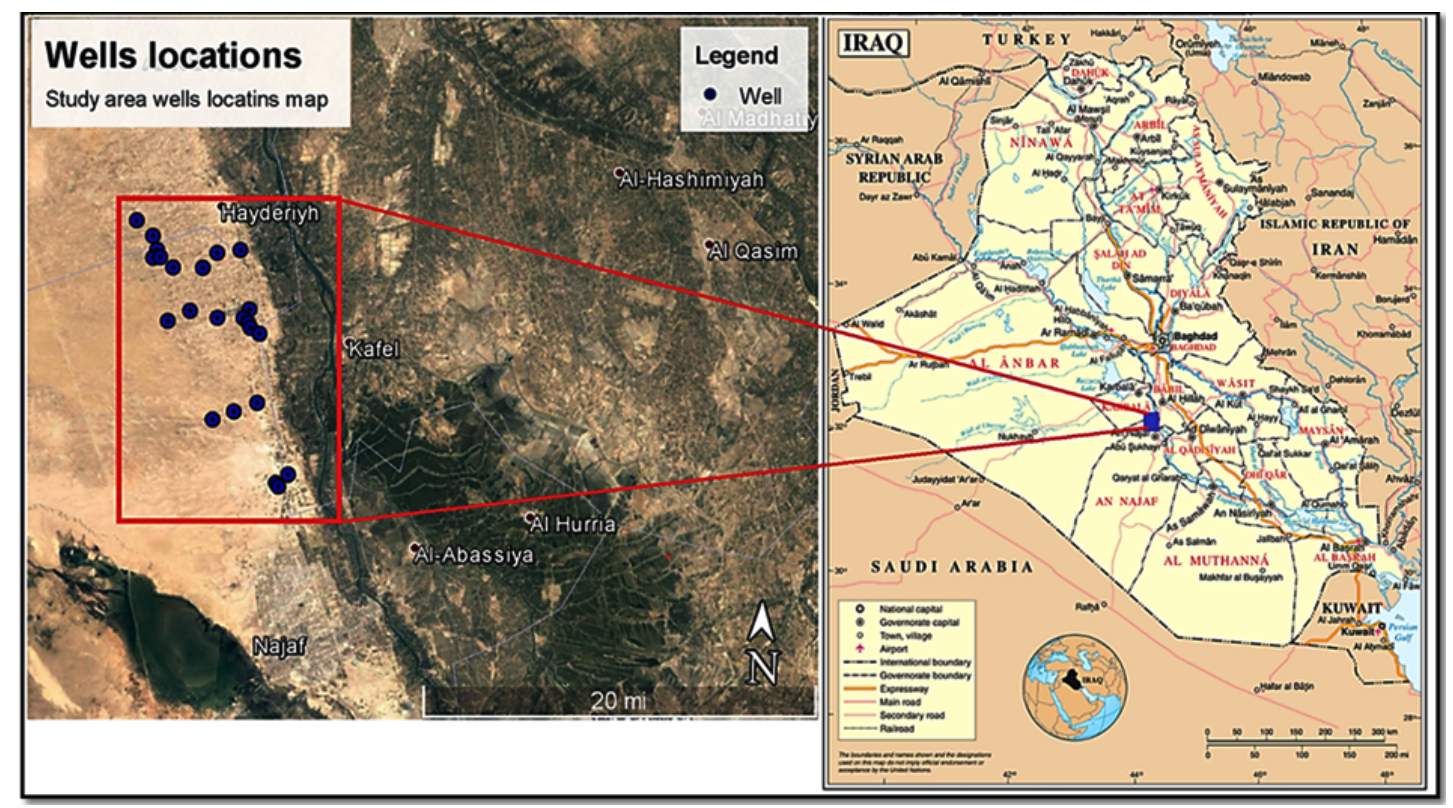

Fig. 2: Study area

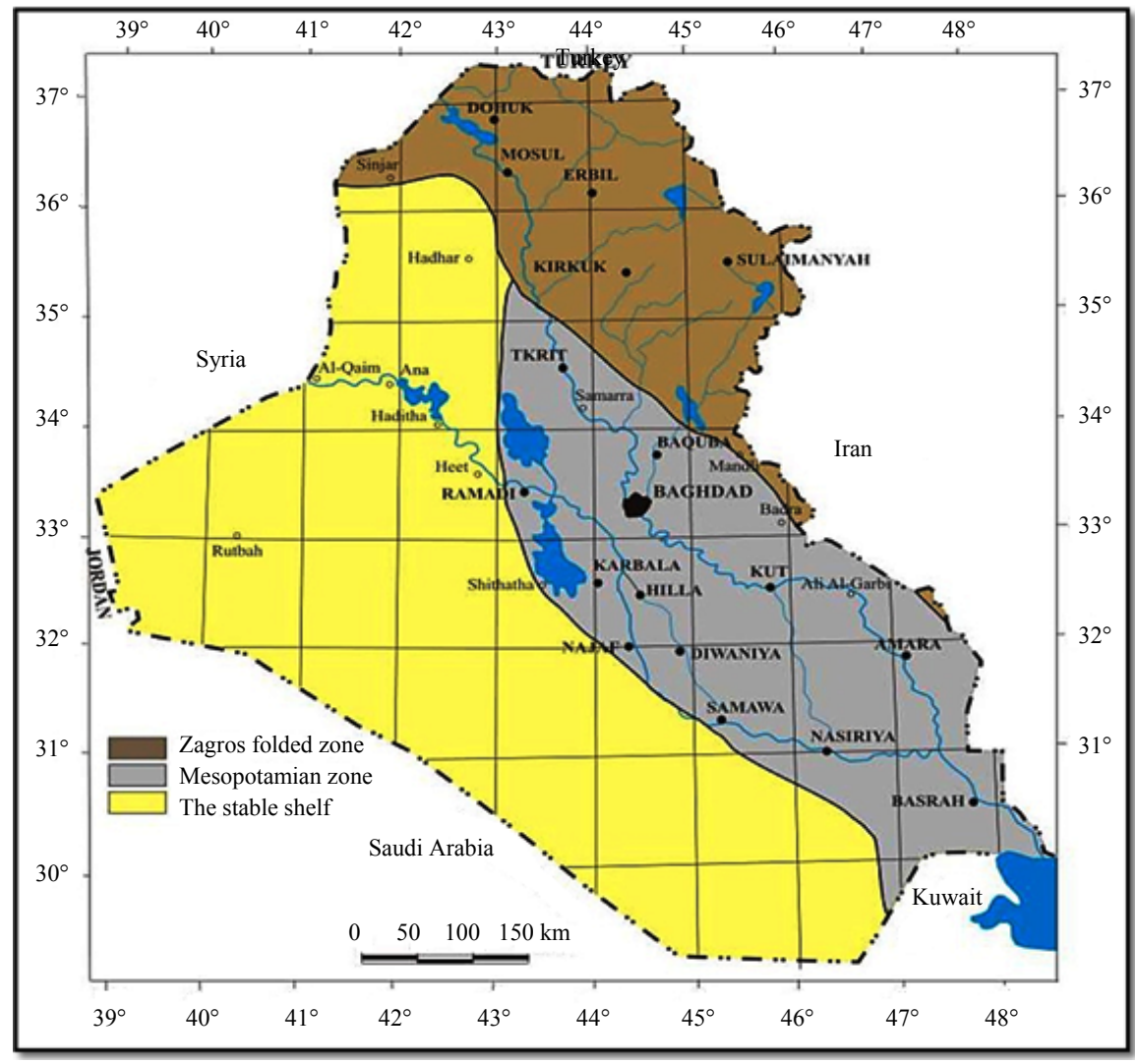

Fig. 3: Tectonic map of Iraq. Buday and Jassim (1987), AlKadhimi et al. (1996) and Jassim and Goff (2006)

nearly 5000 wells were in use in this area in 1998; Abstraction for agricultural uses was estimated at around
370 MCM in the 1980s, a substantial side of the extracted water returns back to groundwater through the porous 


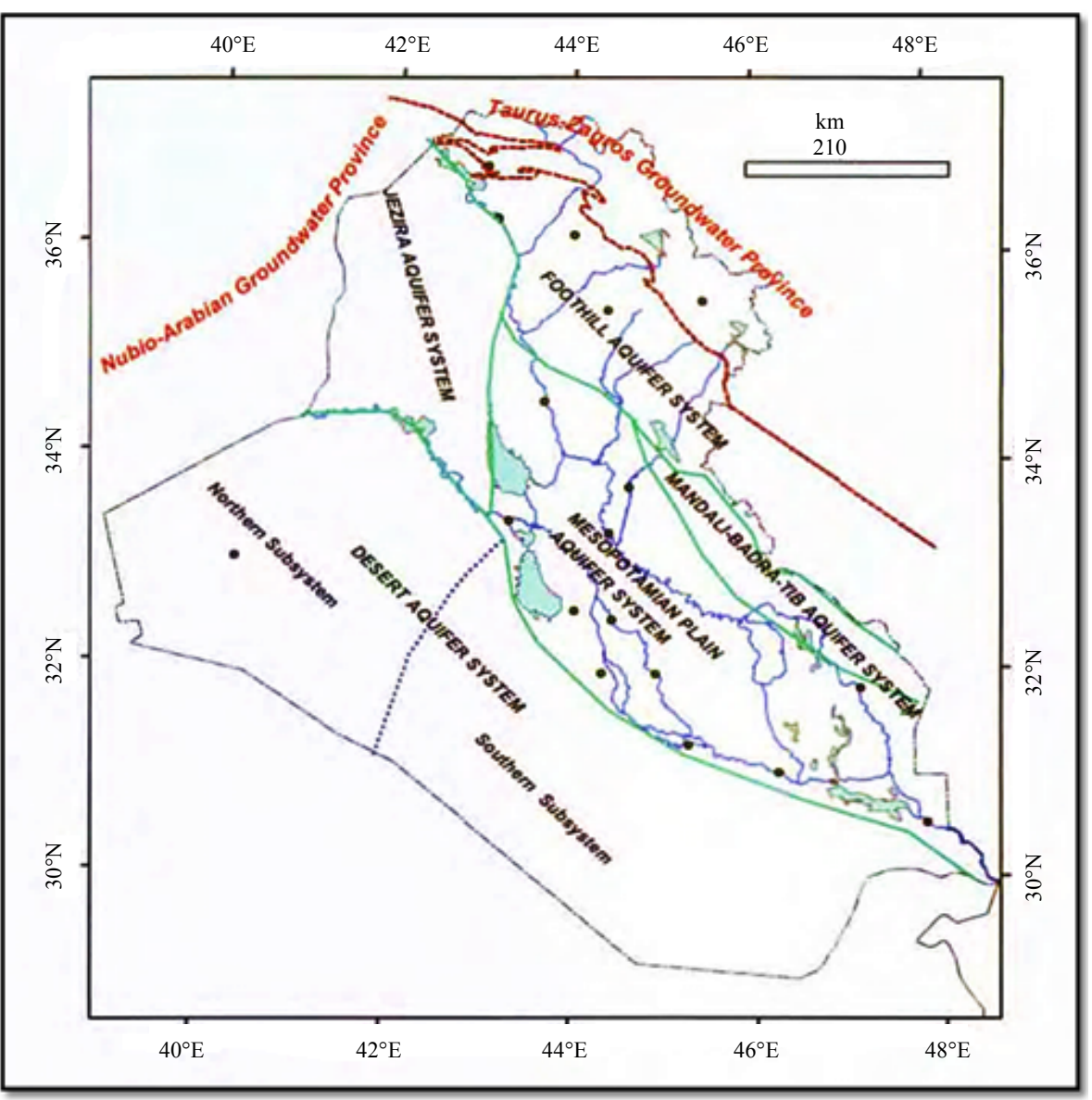

Fig. 4: Major hydrogeological divisions of Iraq. Jassim and Goff (2006)

pebbly sand soils (a return flow of about 84\%) (Hassan et al., 1989). This formation has become hugely unsaturated in different regions, reversing the downward flow of groundwater from the Neogene to the Paleogene formations in heavy abstraction areas (UN-ESCWA and BGR., 2013).

The physicochemical parameters: Depending on the on a range of drilled water wells in the study area where they penetrated the sandy Dibdibba formation. The samples of groundwater were assembled in October 2013 from 23 wells with depth from $(35-52 \mathrm{~m})$. Water samples were obtained in the middle at mid-depth of each well and collected in clear $(3 \mathrm{~L})$ pre-sterilized polyethylene bottles which were washed with distilled water before sampling and transported to the laboratory using standard procedures recommended by standard method for the examination of water and wastewater by American Public Health Association (APHA et al., 1998).

Chemical analysis of water samples analyzed in the laboratories of the general authority of groundwater in Najaf province in the South of Iraq. Various physicochemical parameters $\mathrm{pH}$, total dissolved solids, EC, magnesium, calcium, potassium, sodium, chloride, sulphate, bicarbonate and nitrate have been calculated for all water samples. Groundwater geochemistry is a (cross-sectional study) of water chemistry for the subsurface environment where the chemical structure of the groundwater is the consequence of the water which enters the groundwater reservoir and interactions with rocks that containing different minerals (Appelo and Postma, 1993). This wide range is the conclusion of the difference in origin (sea, air, birth, etc.) the rate of nutrition and interaction with the atmosphere, rock industrial pollution, temperature and pressure (Stuyfzand, 1999).

\section{Statistical analysis}

Water quality index (Wqi): Water quality index is the classification method that provides the combined effect of the individual water quality parameter on the total water quality (Singh et al., 2013). For determine Wqi, a weighted arithmetic index process was used in the present study. Microsoft Office Excel was used to 
J. Eng. Applied Sci., 14 (Special Issue 7): 9995-10009, 2019

Table 1: Study wells values of parameters samples, all parameters units are in $\mathrm{mg} / \mathrm{L}$ except for $\mathrm{pH}$

\begin{tabular}{|c|c|c|c|c|c|c|c|c|c|c|c|}
\hline Well No. & $\mathrm{pH}$ & Ec & TDS & $\mathrm{Ca}^{+2}$ & $\mathrm{Mg}^{+2}$ & $\mathrm{Na}^{+}$ & $\mathrm{K}^{+}$ & $\mathrm{Cl}^{-1}$ & $\mathrm{SO}_{4}^{-2}$ & $\mathrm{HCO}_{3}{ }^{-1}$ & $\mathrm{NO}_{3}^{-1}$ \\
\hline$\overline{\mathrm{W} 01}$ & 7.50 & 3870 & 2675 & 264 & 128 & 420 & 80 & 552 & 1013 & 460 & $\overline{5.2}$ \\
\hline W02 & 7.30 & 4880 & 3218 & 332 & 157 & 536 & 118 & 716 & 1296 & 509 & 3.0 \\
\hline W03 & 7.20 & 5580 & 3801 & 309 & 148 & 548 & 96 & 667 & 1296 & 489 & 1.3 \\
\hline W04 & 7.23 & 5490 & 3734 & 301 & 145 & 542 & 95 & 662 & 1262 & 485 & 1.6 \\
\hline W05 & 7.35 & 3750 & 3256 & 270 & 130 & 510 & 85 & 639 & 1104 & 465 & 2.3 \\
\hline W06 & 7.54 & 5330 & 2599 & 258 & 122.2 & 402.6 & 76.3 & 518 & 984 & 421 & 5.4 \\
\hline W07 & 7.50 & 3970 & 2630 & 290 & 140 & 440 & 102 & 869 & 1089 & 472 & 3.0 \\
\hline W08 & 7.50 & 3920 & 2593 & 280 & 134 & 434 & 95.8 & 596 & 1036 & 469 & 5.0 \\
\hline W09 & 7.60 & 3860 & 2901 & 260.5 & 126.1 & 410.8 & 78.8 & 547 & 1002 & 450.7 & 5.3 \\
\hline W10 & 7.30 & 4350 & 2879 & 314 & 148 & 494 & 110 & 667 & 1214 & 490 & 3.0 \\
\hline W11 & 7.32 & 4020 & 2663 & 295 & 143 & 460 & 106 & 621 & 1142 & 475 & 3.0 \\
\hline W12 & 7.28 & 4630 & 3058 & 312 & 142 & 510 & 95 & 680 & 1181 & 480 & 2.0 \\
\hline W13 & 7.35 & 4860 & 3205 & 330 & 156 & 533 & 116 & 714 & 1286 & 508 & 3.0 \\
\hline W14 & 7.30 & 4520 & 2988 & 300 & 138 & 480 & 85 & 650 & 1123 & 460 & 2.0 \\
\hline W15 & 7.40 & 4460 & 2949 & 260 & 123 & 440 & 72 & 604 & 960 & 430 & 2.0 \\
\hline W16 & 7.20 & 5080 & 3351 & 340 & 165 & 560 & 120 & 746 & 1363 & 512 & 2.0 \\
\hline W17 & 7.12 & 5710 & 3754 & 356 & 173 & 580 & 125 & 781 & 1440 & 514 & 2.0 \\
\hline W18 & 7.20 & 6570 & 3580 & 286 & 139 & 532 & 91 & 651 & 1190 & 481 & 2.1 \\
\hline W19 & 7.30 & 4510 & 2981 & 298 & 136 & 470 & 83 & 645 & 1094 & 458 & 2.0 \\
\hline W20 & 7.12 & 6930 & 4665 & 350 & 172 & 586 & 104 & 692 & 1536 & 508 & 1.1 \\
\hline W21 & 7.12 & 7090 & 4777 & 345 & 170 & 609 & 110 & 705 & 1844 & 510 & 0.8 \\
\hline W22 & 7.12 & 6970 & 4610 & 350 & 170 & 590 & 104 & 703 & 1526 & 506 & 1.1 \\
\hline W23 & 7.18 & 6980 & 4617 & 360 & 180 & 612 & 106 & 715 & 1613 & 508 & 1.1 \\
\hline Max. & 7.60 & 7090 & 4777 & 360 & 180 & 612 & 125 & 869 & 1844 & 514 & 5.4 \\
\hline Min. & 7.12 & 3750 & 2593 & 258 & 122.2 & 402.6 & 72 & 518 & 960 & 421 & 0.8 \\
\hline Median & 7.30 & 4860 & 3205 & 301 & 143 & 510 & 96 & 667 & 1190 & 481 & 2.0 \\
\hline
\end{tabular}

Table 2: Relative weight for each parameter, all units are in $\mathrm{mg} / \mathrm{L}$ except for $\mathrm{pH}$

\begin{tabular}{|c|c|c|c|c|c|c|c|c|c|}
\hline Chemical parameters & $\mathrm{pH}$ & $\mathrm{Ca}^{+2}$ & $\mathrm{Mg}^{+2}$ & $\mathrm{Na}^{+}$ & $\mathrm{K}^{+}$ & $\mathrm{Cl}^{-1}$ & $\mathrm{SO}_{4}^{-2}$ & $\mathrm{HCO}_{3}^{-1}$ & $\mathrm{NO}_{3}^{-1}$ \\
\hline $\begin{array}{l}\text { Highest permitted } \\
\text { value for water }(\mathrm{Si})\end{array}$ & 8.5 & 200 & 150 & 200 & 12 & 600 & 400 & 200 & 50 \\
\hline $1 / \mathrm{Si}$ & 0.117647 & 0.005 & 0.00667 & 0.005 & 0.0833 & 0.00167 & 0.0025 & 0.005 & 0.020 \\
\hline $\mathrm{Wi}=\mathrm{k} / \mathrm{Si}$ & 0.475379 & 0.0202 & 0.02694 & 0.0202 & 0.3367 & 0.00673 & 0.0101 & 0.0202 & 0.0808 \\
\hline \multicolumn{10}{|c|}{$\mathrm{K}=\frac{1}{\sum_{\mathrm{i}=\overline{\mathrm{Si}}}^{\mathrm{n}} \frac{1}{}}=4.04072$} \\
\hline $\begin{array}{l}(\Sigma 1 / \mathrm{Si}) \\
(\Sigma \mathrm{Wi}) \\
\end{array}$ & $\begin{array}{l}=0.247 \\
=1\end{array}$ & & & & & & & & \\
\hline
\end{tabular}

Table 3: The Iraqi standard for drinking purpose

\begin{tabular}{|c|c|c|c|c|c|c|c|c|c|c|}
\hline Parameters & $\mathrm{pH}$ & TDS & $\mathrm{Ca}^{+2}$ & $\mathrm{Mg}^{+2}$ & $\mathrm{Na}^{+}$ & $\mathrm{K}^{+}$ & $\mathrm{Cl}^{-1}$ & $\mathrm{SO}_{4}{ }^{-2}$ & $\mathrm{HCO}_{3}{ }^{-1}$ & $\mathrm{NO}_{3}^{-1}$ \\
\hline Iraqi standard, No. 417 & $6.5-8.5$ & 1500 & 200 & 150 & 200 & 12 & 600 & 400 & 200 & 50 \\
\hline
\end{tabular}

describe statistics of water quality parameters like (median, minimum and maximum) Table 1 and then calculate Wqi for all studied wells.

Step 1: Calculating the constant of proportionality with Eq. 1 (Table 2) as below:

$$
K=\frac{1}{\sum_{i=1}^{n} \frac{1}{S i}}
$$

Where:

$\mathrm{K}$ : Constant of proportionality

$\mathrm{Si}$ : Standard limit for each parameter

$\mathrm{n}$ : Number of parameters

Step 2: Calculating relative Weight (Wi) of each parameter by using Eq. 2 as in Table 2:

$$
\mathrm{Wi}=\frac{\mathrm{K}}{\mathrm{Si}}
$$

Step 3: Calculating quality value scale (qi) for each parameter is allocated by dividing parameter concentration in each sample by its standard value according to Iraqi Standards for drinking purpose by Anonymous (2001) 100 as in Eq. 3:

$$
\mathrm{qi}=(\mathrm{Ci} / \mathrm{Si}) \times 100
$$

Where:

qi : Quality rating

$\mathrm{Ci}$ : Concentration of a single parameter in each sample $\left(\mathrm{mgL}^{-1}\right)$

Si : Iraqi standards for drinking purpose (Table 3)

Step 4: To computing Wqi, according to Ramakrishnaiah et al. (2009) the (SIi) specified for each parameter as in Eq. 4:

$$
\mathrm{Sli}=\mathrm{Wi} * \mathrm{qi}
$$


Table 4: Water quality classification based on Wqi values

\begin{tabular}{ll}
\hline Water quality & Wqi values \\
\hline Excellent & $<50$ \\
Good water & $50-100$ \\
Poor water & $100-200$ \\
Very poor water & $200-300$ \\
Water unsuitable for drinking & $>300$ \\
\hline
\end{tabular}

Table 5: Wqi for study wells

\begin{tabular}{lcl}
\hline Well No. & Wqi values & Water quality \\
\hline 01 & 308.90 & Water unsuitable for drinking \\
02 & 427.91 & Water unsuitable for drinking \\
03 & 359.68 & Water unsuitable for drinking \\
04 & 356.44 & Water unsuitable for drinking \\
05 & 324.88 & Water unsuitable for drinking \\
06 & 296.92 & Very poor water \\
07 & 377.53 & Water unsuitable for drinking \\
08 & 357.79 & Water unsuitable for drinking \\
09 & 305.58 & Water unsuitable for drinking \\
10 & 402.09 & Water unsuitable for drinking \\
11 & 388.86 & Water unsuitable for drinking \\
12 & 356.06 & Water unsuitable for drinking \\
13 & 421.99 & Water unsuitable for drinking \\
14 & 324.69 & Water unsuitable for drinking \\
15 & 283.60 & Very poor water \\
16 & 434.19 & Water unsuitable for drinking \\
17 & 449.88 & Water unsuitable for drinking \\
18 & 343.37 & Water unsuitable for drinking \\
19 & 318.30 & Water unsuitable for drinking \\
20 & 386.02 & Water unsuitable for drinking \\
21 & 405.40 & Water unsuitable for drinking \\
22 & 385.97 & Water unsuitable for drinking \\
23 & 393.27 & Water unsuitable for drinking \\
\hline
\end{tabular}

SIi is first specified for each chemical parameter. Water quality classification based on Wqi values (Table 4) and to calculate the Wqi as the following Eq. 5:

$$
\mathrm{Wqi}=\sum \mathrm{Sli}
$$

Water quality criteria for irrigation: Calculating the Sodium Adsorption Ratio (SAR) in groundwater according to Richards (1954) from the following Eq. 6:

$$
\mathrm{SAR}=\frac{\mathrm{Na}^{+}}{\sqrt{\frac{\left(\mathrm{Ca}^{+2}+\mathrm{Mg}^{+2}\right)}{2}}}
$$

Sodium percentage $(\mathrm{Na} \%)$ is used also for evaluating the suitability of water quality for irrigation (Wilcox, 1955). As for a following Eq. 7 :

$$
\mathrm{Na} \%=\frac{(\mathrm{Na}+\mathrm{K})}{(\mathrm{Ca}+\mathrm{Mg}+\mathrm{Na}+\mathrm{K})} \times 100
$$

Water quality index (wqi) for all study wells are presented in Table 5.

\section{RESULTS AND DISCUSSION}

The potential of Hydrogen ( $\mathbf{p H}$ ): It is the negative logarithm of hydrogen ion activity, a measure of acidity and alkalinity in normal conditions of temperature and pressure (Langmuir, 1997). Solutions with $<7$ are acidic and if it's $>7$ become alkaline, $\mathrm{pH}$ values of this study are ranged from 7.12-7.6 as shown in Fig. 5. The results present that the groundwater in this study resort to neutralize and partly alkaline.

Electrical Conductivity (EC): EC values of the present study are ranged from $3750-7090$ as in Fig. 6. The conductivity of $1 \mathrm{~cm}$ of power at $25^{\circ} \mathrm{C}$ measured in $\mu \mathrm{S} / \mathrm{cm}$ where electrical conductivity is dependent on water temperature increasing the water temperature by $1{ }^{\circ} \mathrm{C}$ causes an increase in electrical conductivity of $2 \%$ and also increased by increasing the dissolved salts concentration (Hem, 1985; Detay, 1997).

Total Dissolved Solids (TDS): TDS values are ranged from $2593-4777 \mathrm{mgL}^{-1}$ as a display in (Fig.7), very high values of TDS were measured in all study wells much further Iraqi drinking water standards (Anonymous, 2001). These values considered not suitable for drinking water.

Cations concentrations: The examination of Calcium ions $\left(\mathrm{Ca}^{+2}\right)$, Magnesium ions $\left(\mathrm{Mg}^{+2}\right)$, sodium ions $\left(\mathrm{Na}^{+}\right)$ and potassium $\left(\mathrm{K}^{+}\right)$, display the range from $258-360$, 122.2-180, 402.6-612 and 72-125 $\mathrm{mgL}^{-1}$ as in Fig. 8-11.

Anions concentrations: The test range of Chloride ions $\left(\mathrm{Cl}^{-1}\right)$, Sulfate $\left(\mathrm{SO}_{4}^{-2}\right)$, bicarbonate $\left(\mathrm{HCO}_{3}{ }^{-1}\right)$ are 518-869, $960-1844$ and $421-514 \mathrm{mgL}^{-1}$ as Fig. 12-14.

Nitrate $\left(\mathrm{NO}_{3}{ }^{-1}\right)$ : Various agricultural activities increase the concentration of nitrates in ground and surface water (Nas and Ali, 2006). The range of nitrate is from (0.8-5.4 $\left.\mathrm{mgL}^{-1}\right)$ as a display in Fig. 15 where its concentration did not exceed the required limit in all samples values for study wells.

Sodium Absorption Ratio (SAR): Groundwater may also classify based on Sodium Absorption Ratio (SAR) as excellent 10, good 10-18, questionable 18-26 and unsuitable ( $>26)$ (Richards, 1954). In order to assess the suitability of the wells for irrigation in the study area Fig. 16.

Sodium percentage $(\mathbf{N a} \%)$ : Sodium concentration is an important role in evaluating the irrigational quality of groundwater where the soil of the area study is saline soil according to the high percentage of sodium shows a positive correlation with high salinity soil salinity Fig. 17, the significant positive correlation between soil salinity and the sodium percentage (Lehman et al., 2015). 


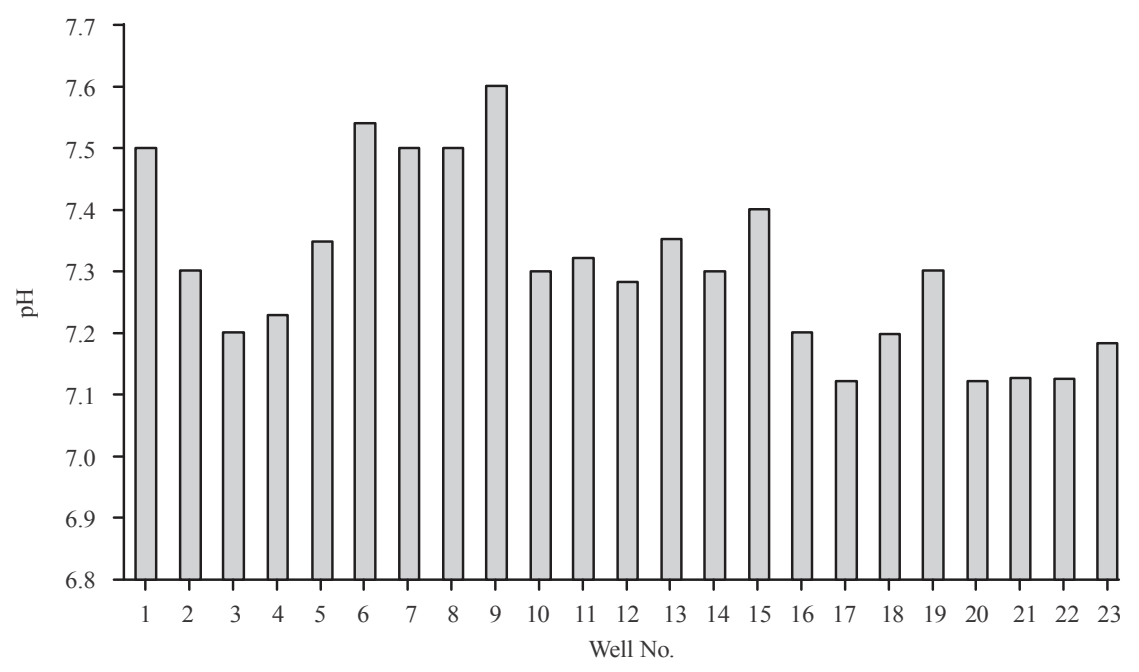

Fig. 5: $\mathrm{pH}$ values for all study wells

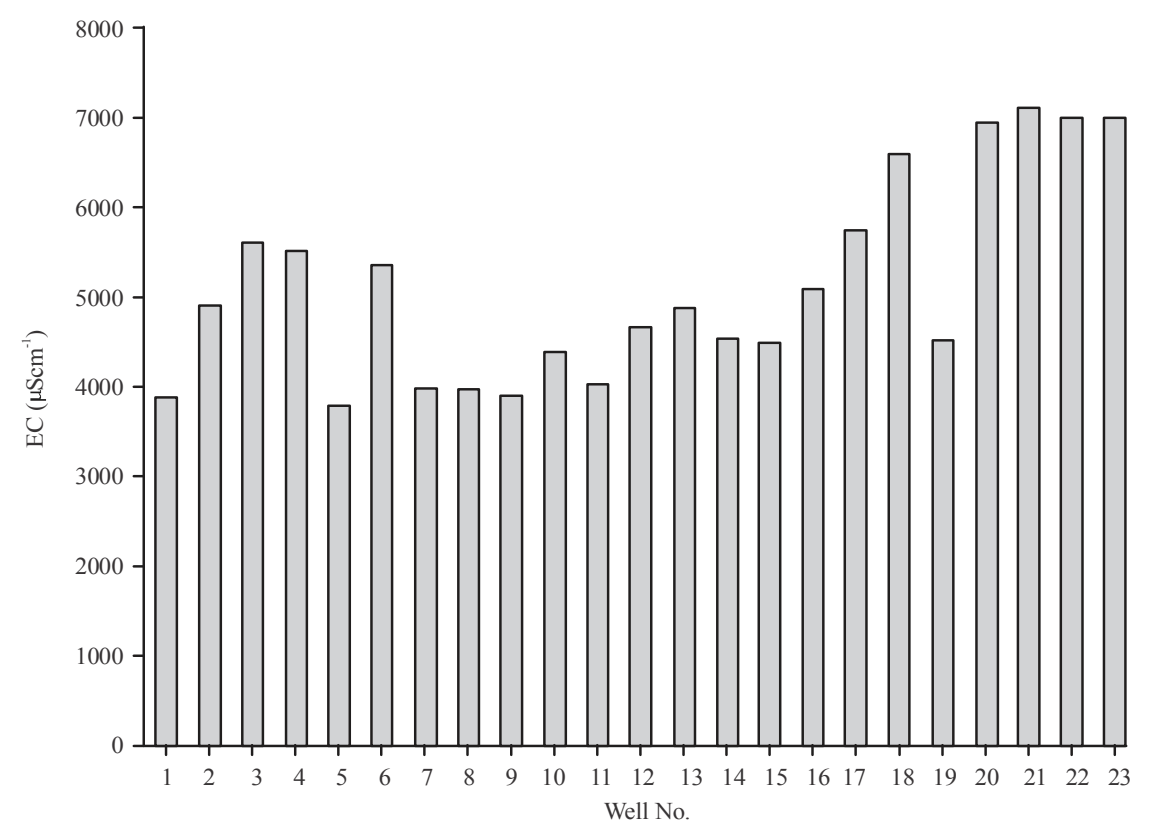

Fig. 6: EC values for all study wells

The aquifer is essentially recharged from rainfall, since, it is located in an arid environment where rainfall is rare and restricted within slight Winter months, so, the aquifer is not fully saturated and many of its large parts are lacking sufficient groundwater, however, the saturated thickness is growing to the West. The aquifer is usually unconfined in its Western parts and moved towards the East, therefore, the clay and marl lenses inside the formation retain water in isolated sandy lenses.

The previous studies on this aquifer specified that the Western parts of it are nearly dry and therefore inappropriate for exploitation projects where the Eastern parts are more promising (Joshi et al., 2009; Al-Ani,
2004). The irregular investment of groundwater of this aquifer is very chancy where different parts of the aquifer set positive and negative productivity of water use together (Buxton and Smolensky, 1999; Leijnse and Hassanizadeh, 1994). The results are shown by the physical and chemical values of parameters of the study wells samples as agreeing with the Iraqi drinking water standards (Anonymous, 2001).

The $\mathrm{pH}$ observed values 7.12-7.6 are consistent with the Iraqi drinking water standards with ranges from 6.5-8.5 and showed that the groundwater head for neutralizing or slightly alkaline. The massive rates of TDS concentration due to the gypsum, sand and silty clay in 


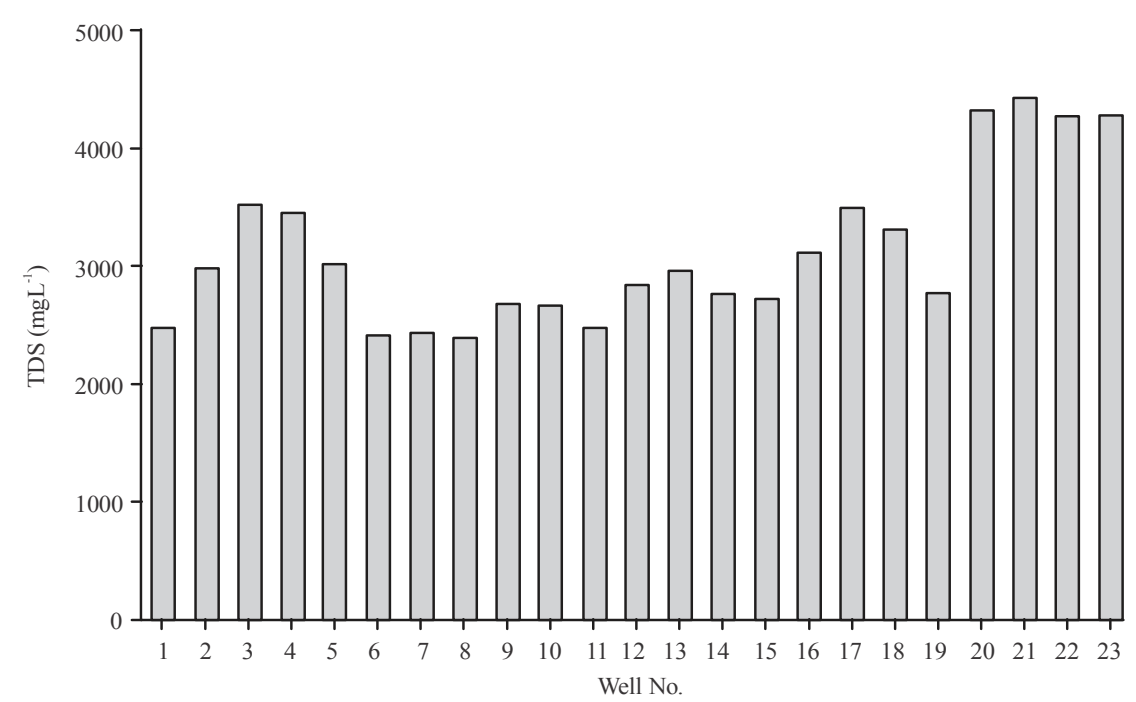

Fig. 7: TDS values for all study wells

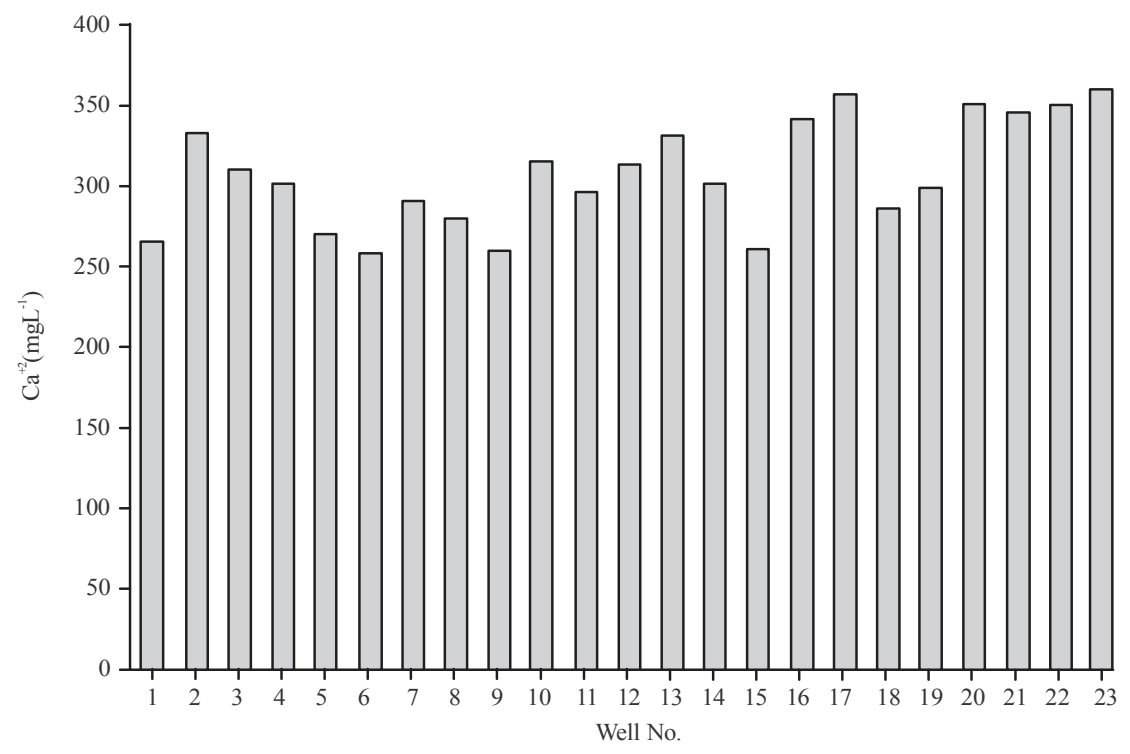

Fig. 8: $\mathrm{Ca}^{+2}$ values for all study wells

the chemical composition of the formation. The geological nature of this formation reflects the high and low concentration of calcium. The values of magnesium are within acceptable and permissible limits by comparing them to specifications Iraqi drinking water standards. Sodium is present in the groundwater due to the ease of melting of sodium salts in water (Desonie, 2008). The study showed high rates of potassium and these high concentrations minimizes plant uptake of calcium (Ayers and Westcot, 1985). High chloride concentration in dry areas due to its spread in all rocks and crust sediments where the chlorides are spread on the surface of the earth in the form of sodium and potassium chlorides the most important elements of water and the sense of salt taste of water depends on the positive side of chlorides and high concentration of chloride ion is often shaped as sodium chloride and gives the taste of salt (Berkowitz et al., 2008), this high concentration of chloride points out there is a high percentage of organic pollution can occur near sewage and waste of factories, results water distasteful and unsuitable for drinking and watering cattle (Chapman, 1998). High values of sulfate due to the presence of large amounts of gypsum materials where the sodium sulfate the main source of sulfate in groundwater and the high concentration of it causes a difference in the taste of water. All study wells tend to alkalinity due to the presence of hydroxide, carbonates and bicarbonates ions 


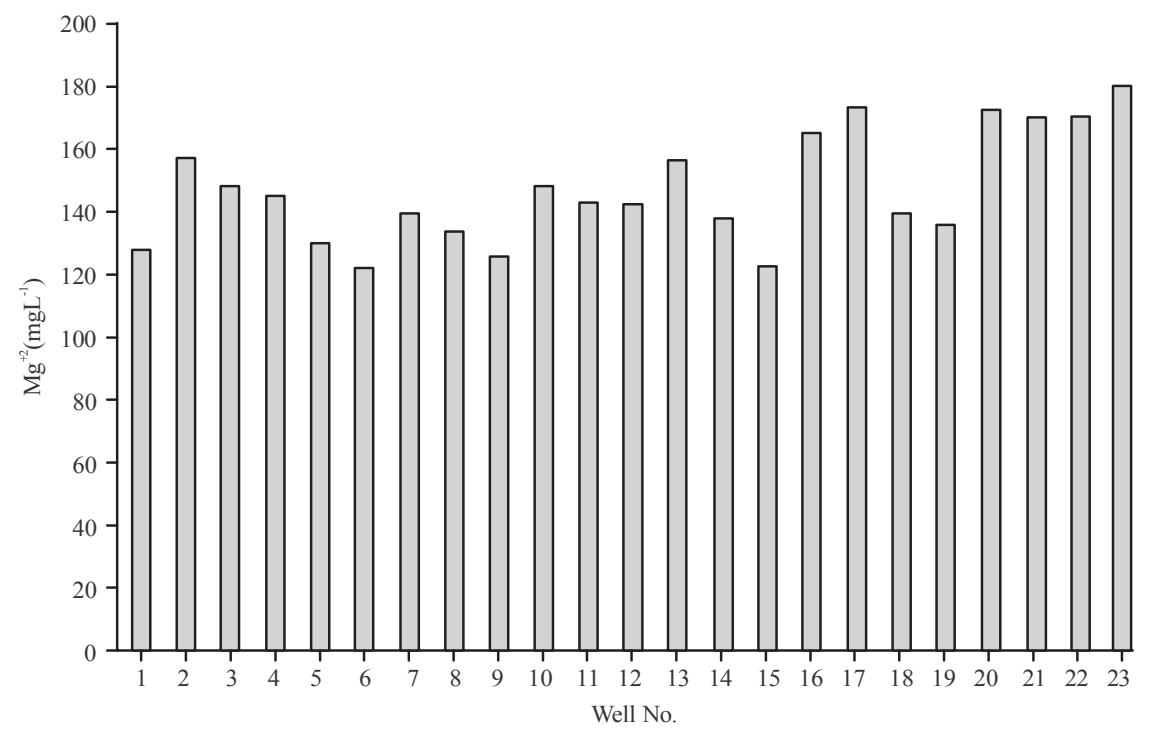

Fig. 9: $\mathrm{Mg}^{+2}$ values for all study wells

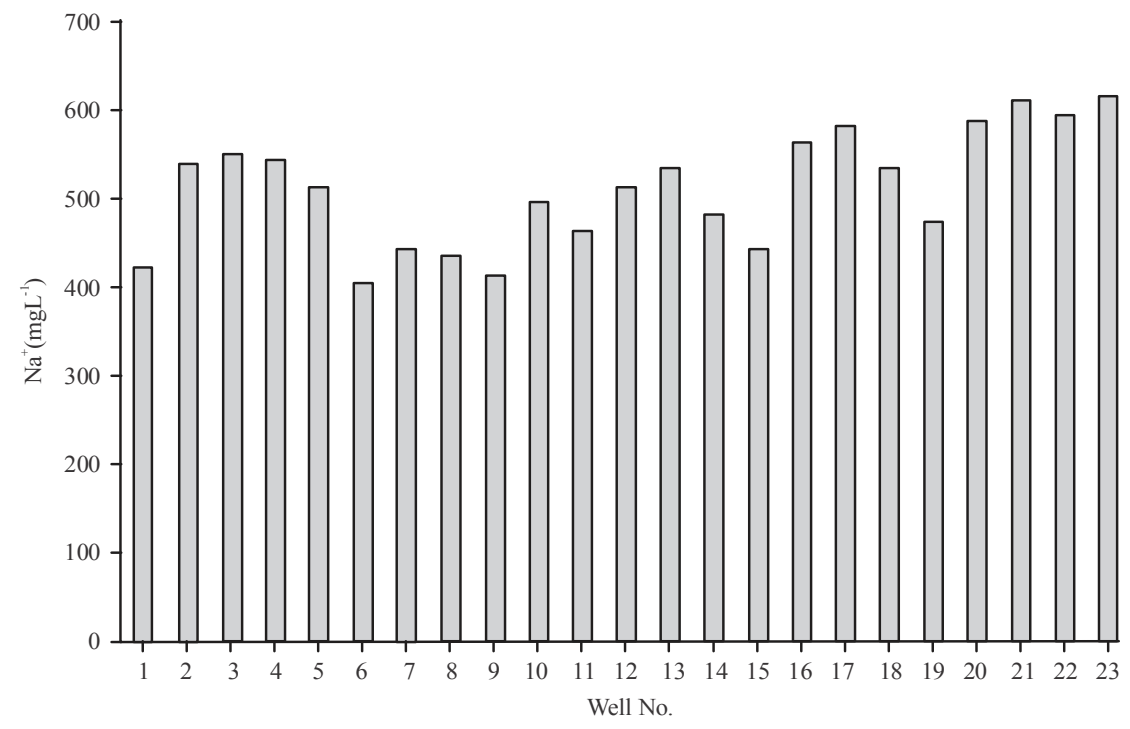

Fig. 10: $\mathrm{Na}^{+}$values for all study wells

in water (Merkel and Planer-Friedrich, 2008). Nitrate concentration is very low in all study wells which is below the Iraqi drinking water standards (Anonymous, 2001). The previous studies from the state company of geological survey and mining in Iraq presented that the groundwater flow direction of the study area is from west to East and from the Southwest to the Northeast (Ayob et al., 1995; Al-Jiburi, 2002).

This activity increased groundwater contamination due to dissolved rocks in different chemical composition through the distance traveled up to reach locations of selected wells. The other cause for the high values of wqi is a persistent emptying of agricultural flow. When comparing the positive and negative ion concentrations and the total salinity of the groundwater samples, there are no wells within the permissible limits for use for drinking purposes. Groundwater validity for irrigation purposes depends on the ion concentrations in the water mainly taking into consideration the salt content expressed by electrical conductivity (Ayers and Westcot, 1985) (Fig. 18 and 19).

Increased $\mathrm{Na} \%$ in water leads to reduced soil permeability due to the exchange of calcium ion and magnesium with sodium in the soil (Rasul, 2000). Therefore, it a risk and causes problems for irrigation, groundwater cannot be used for human consumption as a result of the high concentration of salinity and major ions in the wells. When using the (Richards, 1954) 
J. Eng. Applied Sci., 14 (Special Issue 7): 9995-10009, 2019

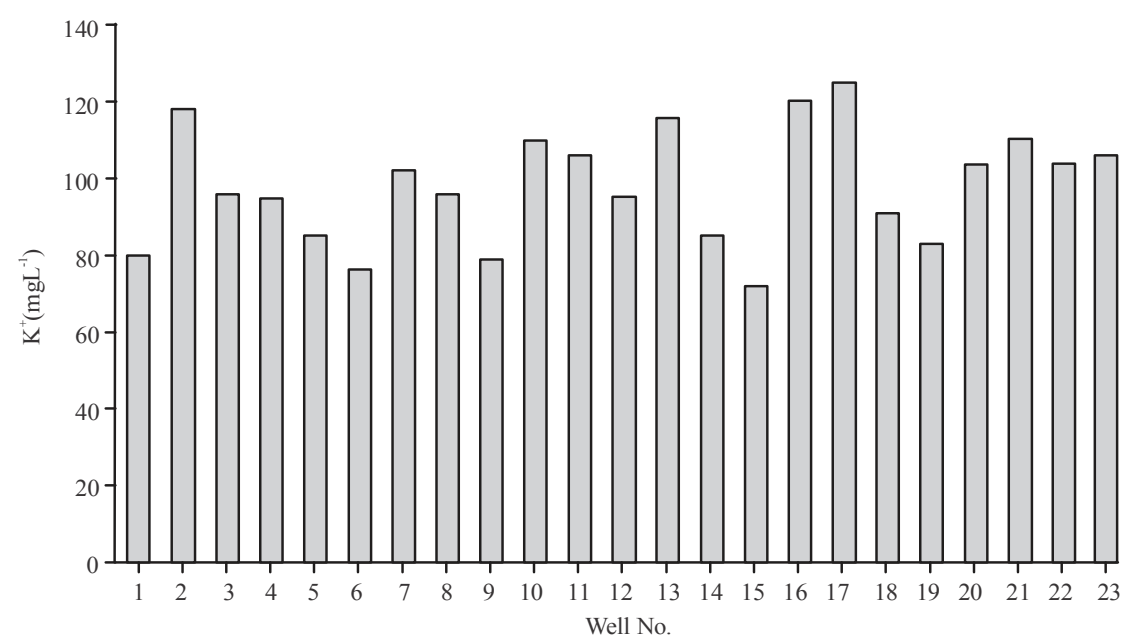

Fig. 11: $\mathrm{K}^{+1}$ values for all study wells

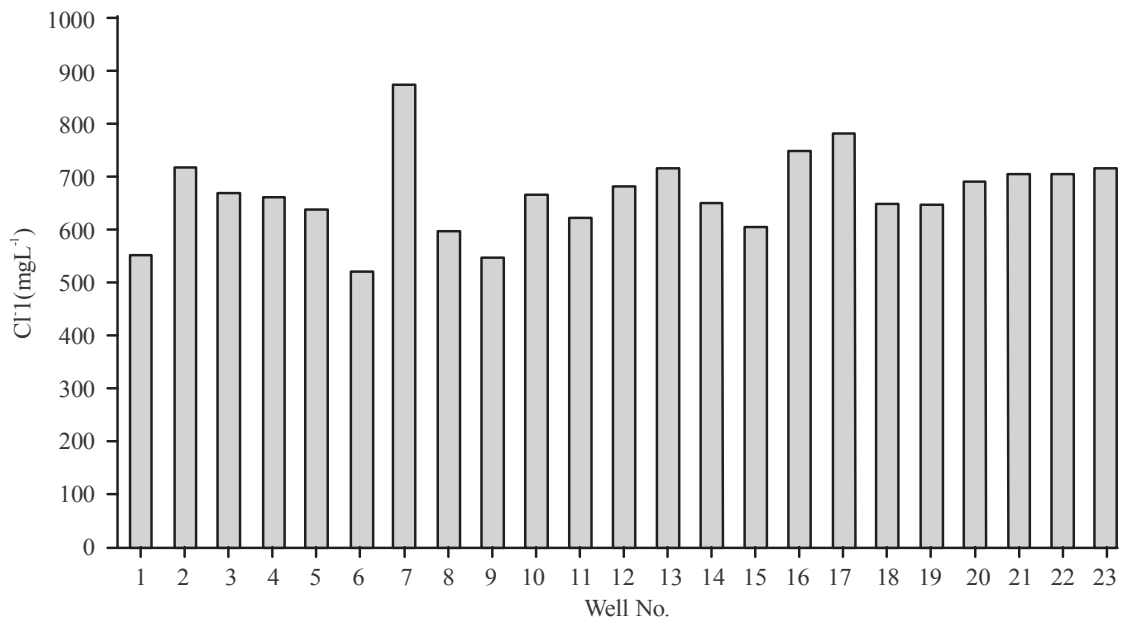

Fig. 12: $\mathrm{Cl}^{-1}$ values for all study wells

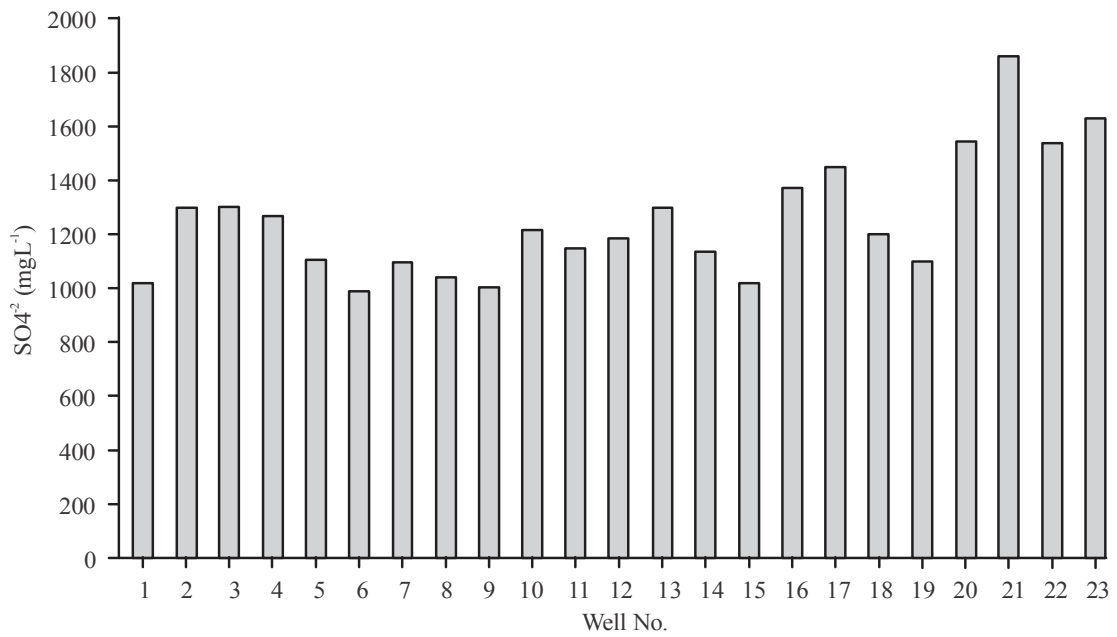

Fig. 13: $\mathrm{SO}_{4}^{-2}$ values for all study wells 
J. Eng. Applied Sci., 14 (Special Issue 7): 9995-10009, 2019

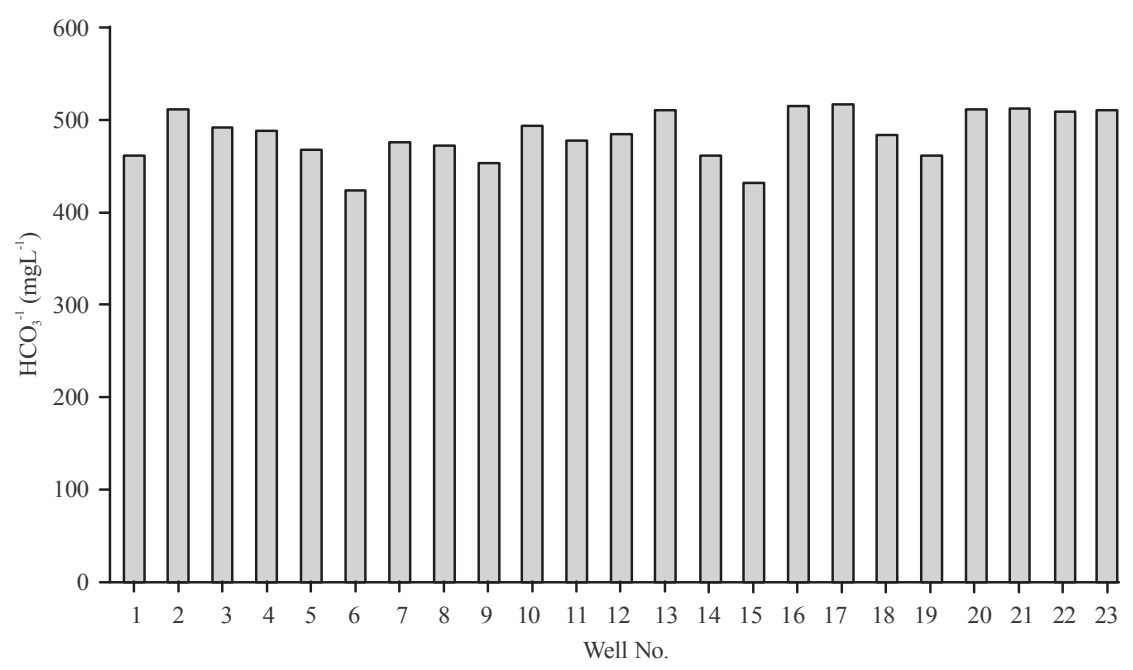

Fig. 14: $\mathrm{HCO}_{3}^{-1}$ values for all study wells

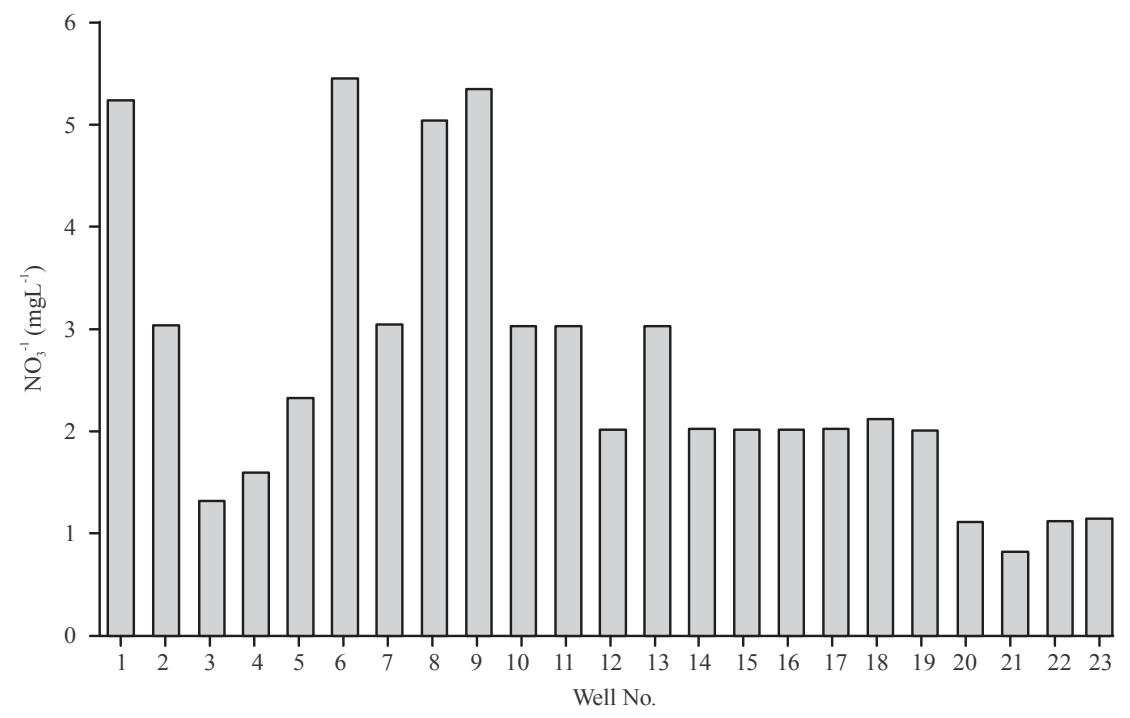

Fig. 15: $\mathrm{NO}_{3}^{-1}$ values for all study wells

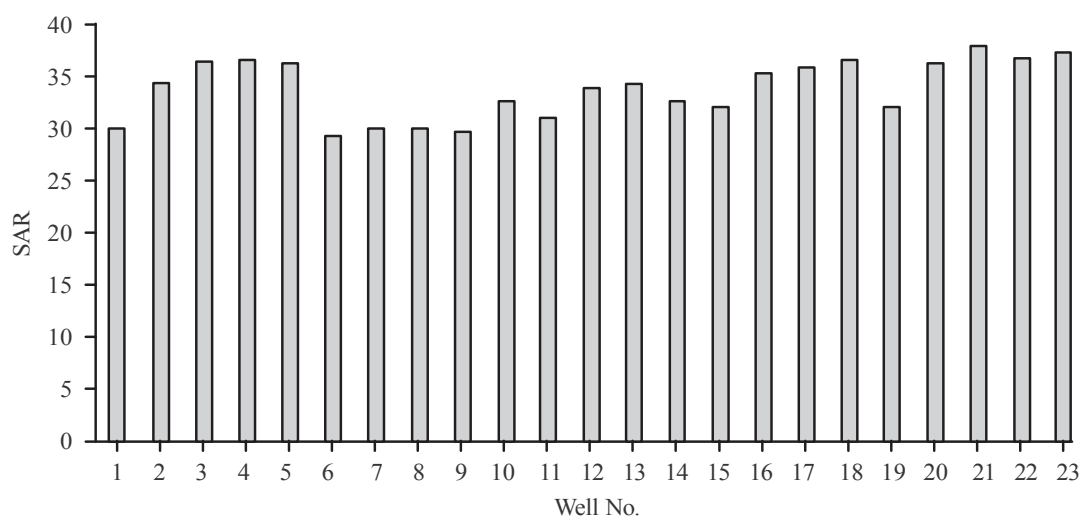

Fig. 16: Sodium Absorption Ratio (SAR) for all study wells 


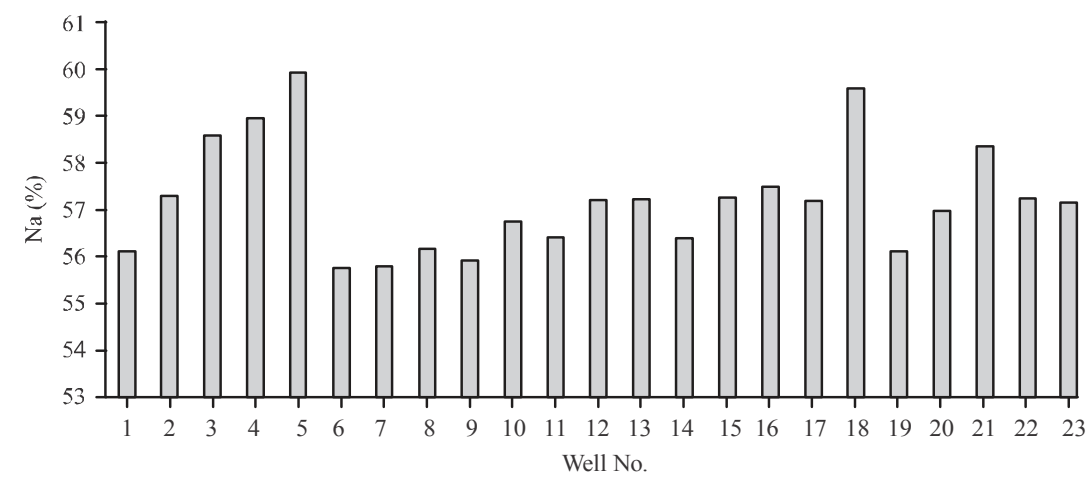

Fig. 17: Sodium percentage ( $\mathrm{Na} \%)$ for all study wells

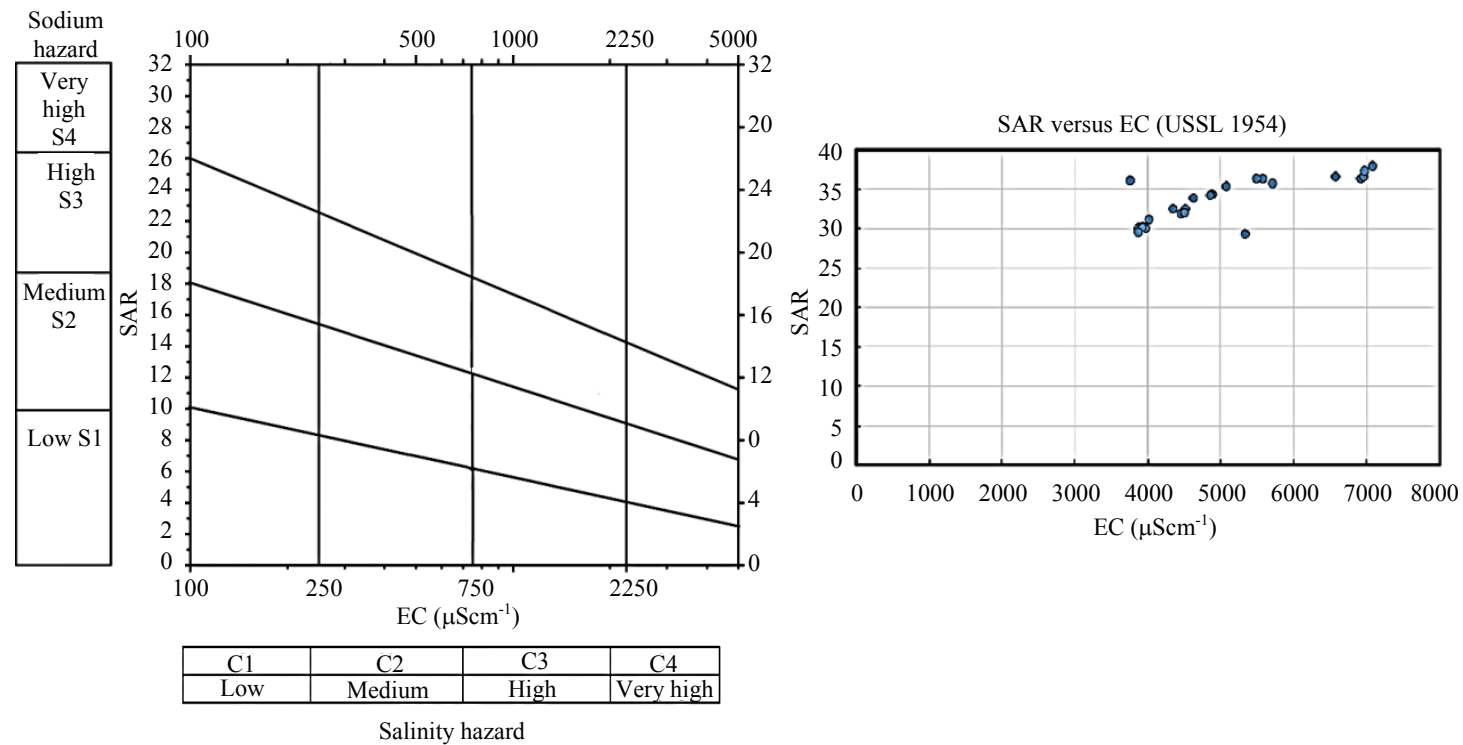

Fig. 18: Classification of groundwater based on SAR and EC for irrigation purposes (after the US Salinity laboratory, Richards (1954)

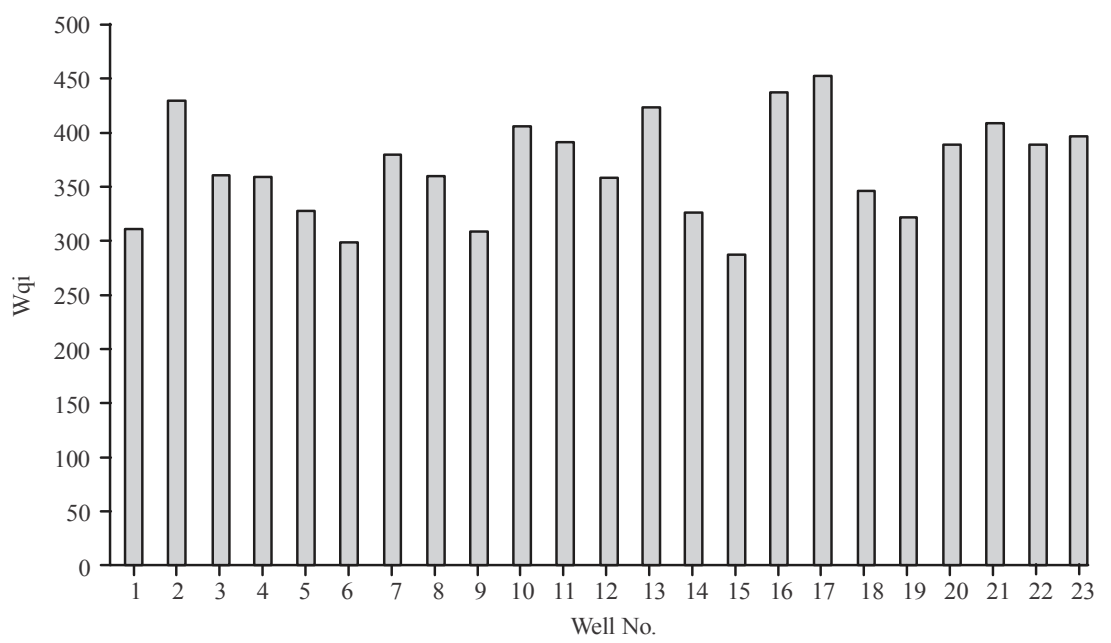

Fig. 19: Wqi for all wells samples 
classification which is based on the relationship between Sodium Adsorption (SAR) and Electrical Conductivity (EC) as in Fig. 18 and 19, it is not admissible for irrigation purposes.

It is necessary to place the wells in the study area under a periodic monitoring plan for the underground levels to ensure the safe and non-invasive exploitation of reservoirs of the underground reservoirs by devising a calculated plan for the number and areas of spread of the observation wells that can be drilled and to use them in determining the levels of fluctuation in the underground levels and calculating the natural recharge of the reservoirs and the limits of their variation and the circumstances affecting on it Fig. 19.

\section{CONCLUSION}

The Wqi for 23 samples ranges from 283.60-449.88 two wells samples show values between 283.60-296.92 which are very poor quality for drinking water and twenty-one wells samples display values between 305.58-449.88 and that is mean the water is unsuitable for drinking.

From Wqi values, it is very important to suggest further improvement is required to treat the wells for using for drinking purpose. The looseness of groundwater quality because of the high concentration of TDS and Sulfate $\mathrm{SO}_{4}^{-2}$. The analysis offers that study area groundwater needs good processing and protection from the contamination before any consumption. Wqi values at all wells are much above 300 indicating unfit for drinking purpose.

According to Ramakrishnaiah et al. (2009), the main causes of quality degradation of groundwater are the high concentration of TDS and sulfate in study wells. The stratigraphic sequence of Dibidibba formation consists of several layers of sand permeated by clay and gravel deposits making it a good layer to contain the water and passes through it but the water storage of this reservoir began depletion as a result of the digging large number of short depth wells in addition to low levels of natural recharge of the rain and surface torrents as well as the limited deployment of the reservoir and its surface effects have another negative effect to not relying on this reservoir in the future but explore and study other formations located below it within the stratigraphic column of the area.

The elevation of alkalinity is due to presence hydroxide ions and bicarbonates in water as groundwater contains a small percentage of soluble matter and this indicates the presence of some organic substances soluble in water like calcium salts, magnesium, sodium, potassium, chloride, sulfates, nitrates and due to calcium, magnesium and their salts are the most common elements in the Earth's crust.

The study concluded that geological formation is contributed as main determinants of groundwater quality, since, the existence of each of sulfate and chloride in the solubility of sulfur salts such as gypsum, anhydrite and halite which are commonly found in the majority of the study area. As for the use of irrigation, must be it treated very cautiously also it requires a series of irrigation measures and improve quality.

\section{ACKNOWLEDGEMENT}

First of all, we are grateful to the general authority of groundwater in Najaf province in Iraq for allowing us to perform all our field experiments, chemical analysis of wells in the study area. Thanks to the Ministry of Higher Education and Scientific Research in Iraq for their financial aid. We also express our gratitude to Laboratoire Chrono-Environment (UMR 6249-CNRS), Universite de Franche-Comte (Besancon, France) for the precious help during all work steps.

\section{REFERENCES}

APHA, AWWA and WEF., 1998. Standard Methods for the Examination of Water and Wastewater. 20th Edn., American Public Health Association/ American Water Works Association/Water Environment Federation, Washington, DC., USA., ISBN-13: 9780875532356, Pages: 1220.

Al-Ani, A.R., 2004. Estimation of groundwater recharge in the arid and semiarid regions (Dibdiba formation in the area of Karbala-Najaf). Ph.D Thesis, University of Baghdad, Baghdad, Iraq.

Al-Jawad, S.B., F.H. Naom, D.Y. Bashuand and H.L. Zamil, 2001. The hydrogeology of aquifers in the Iraqi Western Desert South of the Euphrates River. Ministry of Agriculture in Iraq, Baghdad. https://apps.geodan.nl/igrac/ggis-viewer/mim/ documents/view/13201055

Al-Jiburi, H.K., 2002. Hydrological and hydrochemical study of Kerbala. Quadrangle Sheet (NI-38-14), State Company of Geological Survey and Mining, Baghdad, Iraq.

Al-Naqib, K.M., 1963. Geology of the Arabian Peninsula Southwestern Iraq. Professional paper: 560-G, United States Geological Survey, Reston, Virginia, USA.

AlKadhimi, J.A.M., V.K. Sissakian, A.S. Fattah and D.B. Deikran, 1996. Tectonic Map of Iraq, Scale 1: 1000 000. 2nd Edn., GEOSURV, Baghdad, Iraq, pp: $1-38$.

Alsam, S., S.Z. Jassim and F. Hanna, 1990. Water balance of Iraq: Stage 2, geological and hydrogeological conditions. Manuscript Report, Ministry of Irrigation, Iraq.

Alsharhan, A.S. and A.E.M. Nairn, 1997. Sedimentary Basins and Petroleum Geology of the Middle East. 1st Edn., Elsevier Science, UK., Pages: 843.

Anonymous, 2001. Central organization for quality control and standardization. Council of Ministers, Iraqi Drinking Water Standard (IQS), Iraq. 
Appelo, C.A.J. and D. Postma, 1993. Geochemistry, Groundwater and Pollution. 3rd Edn., AA Balkema, Rotterdam, Netherlands, ISBN:9789054101062, Pages: 536.

Ayers, R.S. and D.W. Westcot, 1985. Water Quality for Agriculture. Food and Agriculture Organization of United Nations, Rome, Italy.

Ayob, M.S., S.K. Ismail and B.M. Ali, 1995. Project to reduce groundwater levels in Kerbala city, AL-Furat center for irrigation studies. State for the operation of irrigation projects, Ministry of Water Resources, Baghdad, Iraq.

Berkowitz, B., I. Dror and B. Yaron, 2008. Contaminant Geochemistry: Interactions and Transport in the Subsurface Environment. Springer, Berlin, Germany, ISBN: 978-3-540-74381-1, Pages: 412.

Brown, R.M., N.I. McClelland, R.A. Deininger and R.G. Tozer, 1970. A water quality index: Do we dare?. Water Sewage Works, 117: 339-343.

Buday, T. and S.Z. Jassim, 1987. The Regional Geology of Iraq, Vol. 2, Tectonism, Magmatism and Metamorphism. Publication of the Geological Survey of Iraq, Baghdad, Iraq, Pages: 352.

Buxton, H.T. and D.A. Smolensky, 1999. Simulation of the effects of development of the ground-water flow system of Long Island, New York. Water-Resources Investigations Report 98-4069, United States Geological Survey, Reston, Virginia, USA. https://pubs.usgs.gov/wri/wri984069/pdf/wrir_984069.pdf

Chapman, D., 1998. Water Quality Assessment: A Guide to the use of Biota Sediments in Environmental Monitoring. Chapman Hall, London, UK.,.

Desonie, D., 2008. Hydrosphere: Freshwater Systems and Pollution. Chelsea House, New York, USA., ISBN-13: 978-0-8160-6215-7, Pages: 188.

Detay, M., 1997. Water Wells: Implementation, Maintenance and Restoration. John Wiley and Sons, London, England, UK., ISBN: 978-0-471-96695-1, Pages: 394.

Elliot, E.K., J.M. Cox and A.V. James, 1954. Report on Twai al Hashash and Khobrar Rachi axis, winter and spring season: 1953-54. Manuscript report No. BGR 23, INOC Library, Baghdad, Iraq.

Hassan, H.A., S.K. Ismail and M. Al-Dabbas, 1989. Regional hydrogeological condition of Dibdibba Basin, Southern Iraq. J. Agric. Water Resour. Res., 8: 167-180.

Hem, J.D., 1985. Study and Interpretation of the Chemical Characteristics of Natural Water. 3rd Edn.,/Vol. 2254, Department of the Interior, US Geological Survey, Reston, Virginia, USA., Pages: 263.

Horton, R.K., 1965. An index number system for rating water quality. J. Water Pollut. Control Fed., 37: 300-305.
Jassim, S.Z. and J.C. Goff, 2006. Geology of Iraq. Dolin, Prague and Moravian Museure, Brno, Czech Republic, Pages: 341.

Joshi, D.M., A. Kumar and N. Agrawal, 2009. Studies on physicochemical parameters to assess the water quality of river Ganga for drinking purpose in Haridwar district. Rasayan J. Chem., 2: 195-203.

Kasim, F.A.A., 1960. Final well report on Kifl No.1. Manuscript report No. FEW 30, INOC Library, Baghdad, Iraq.

Kasim, F.A.A., 1962. Final well report on Mussaiyiab No. 1. Manuscript Report No. FWR 37, INOC Library, Baghdad, Iraq.

Langmuir, D., 1997. Aqueous Environmental Geochemistry. 1st Edn., Prentic-Hall, Inc., USA., ISBN-13: 9780023674129, Pages: 600.

Lehman, R.M., C.A. Cambardella, D.E. Stott, V. Acosta-Martinez and D.K. Manter et al., 2015. Understanding and enhancing soil biological health: The solution for reversing soil degradation. Sustainability, 7: 988-1027.

Leijnse, A. and S.M. Hassanizadeh, 1994. Model definition and model validation. Adv. Water Resour., 17: 197-200.

Merkel, B.J. and B. Planer-Friedrich, 2008. Groundwater Geochemistry: A Practical Guide to the Modeling of Natural and Contaminated Aquatic Systems. 2nd Edn., Springer, Berlin, Germany, ISBN: 978-3-540-74668-3, Pages: 230.

Mohammad, A.B., 2012. Hydrogeological study of the area between Najaf and Karbala cities. Iraqi J. Sci., 53: 353-361.

Nas, B. and B. Ali, 2006. Groundwater contamination by nitrates in the city of Konya, (Turkey): A GIS perspective. J. Environ. Manage., 79: 30-37.

Owen, R.M.S. and S.N. Nasr, 1958. Stratigraphy of the Kuwait-Basrah areas, the habitat of oil, petrology geology: 1252-1278. Pollut. Control Fed., 37: 300-305.

Ramakrishnaiah, C.R., C. Sadashivaiah and G. Ranganna, 2009. Assessment of water quality index for the groundwater in Tumkur Taluk, Karnataka State, India. E-J. Chem., 6: 523-530.

Rasul, G.A.M., 2000. Study of water quality and its effect on nutrients availability for corn in Sulaimani region. MSc Thesis, University of Sulaymaniyah, Sulaymaniyah, Kurdistan Region.

Richards, L.A., 1954. Diagnosis and Improvement of Saline and Alkali Soils. United State Government Printing Office, Washington, DC., USA., Pages: 160. 
Sargaonkar, A. and V. Deshpande, 2003. Development of an overall index of pollution for surface water based on a general classification scheme in Indian context. Environ. Monit. Assess., 89: 43-67.

Singh, A.K., B. Raj, A.K. Tiwari and M.K. Mahato, 2013. Evaluation of hydrogeochemical processes and groundwater quality in the Jhansi district of Bundelkhand region, India. Environ. Earth Sci., 70: 1225-1247.

Stuyfzand, P.J., 1999. Patterns in groundwater Chemistry resulting from groundwater flow. Hydrol. J., 7: 15-27.
UN-ESCWA and BGR., 2013. Inventory of shared water resources in Western Asia. Final Report, United Nations Economic and Social Commission for Western Asia, Beirut Lebanon.

Wilcox, L.V., 1955. Classification and use of irrigation waters. USDA Circular No. 969, U.S. Department of Agriculture, USA.

Yogedra, K. and E.T. Puttaiah, 2008. Determination of water quality index and suitability of an urban waterbody in Shimga town, Karnatka. Proceedings of the Taal2007: The 12th World Lake Conference, October 29- November 2, Jaipur, India, pp: 342-346. 